\title{
KESELAMATAN UNIVERSALISME VERSUS SOTERIOLOGI KRISTEN DALAM PERSPEKTIF ALKITAB
}

\author{
Altin Sihombing \\ Sekolah Tinggi Teologi Samuel Elizabeth \\ altinsihombing@gerejalokal.or.id
}

\begin{abstract}
Many teachings about the salvation that developed in Christianity, in generally rests on the Lord Jesus as a way of salvation. However, the teaching of universalism is deviating from the Bible and misleading many people. Therefore, the author was inspirated to write the Salvation of Universalism Versus Christian Soteriology in the Bible Persfective. Through this article, the author wants to criticize the teaching of universalism based on the Bible so that it can find a true understanding of salvation based on the Bible. Based on the results of the reseach found that the teaching of universalism is contrary to the Bible because it believes that ultimately all humans will be saved. However, it is based on the Bible that there are people who get saved and some who have perished or been punished; Universalism also believes that because of God's grace all people will be saved. But based on the Bible it can be seen that God's so loved the world so that He gave His only begotten Son. As soon as the Lord Jesus died on the cross, there is a turning point - only those who believe get saved, while those who do not believe in the Lord Jesus will perish forever; In addition, universalism also believes that humans can save themselves through good deeds. But the Bible teaches that humans are saved because of God's grace and because of faith in the Lord Jesus. Human good deeds are not able to save humans.
\end{abstract}

Keywords : universalism; saved; believe ; bible.

\begin{abstract}
ABSTRAK
Banyak paham tentang keselamatan yang berkembang di kalangan kekristenan yang pada umumnya betumpu pada Tuhan Yesus sebagai jalan keselamatan. Namun, paham universalisme adalah menyimpang dari Alkitab dan menyesatkan banyak orang. Karena itu, penulis tergerak untuk menulis Keselamatan Universalisme Versus Soteriologi Kristen Dalam Persfektif Alkitab. Melalui tulisan ini, penulis ingin mengkritisasi paham universalisme berdasarkan Alkitab sehingga dapat menemukan pemahaman yang sejati tentang keselamatan berdasarkan Alkitab. Berdasarkan hasil penelitian didapat bahwa paham universlisme bertentangan dengan Alkitab karena meyakini bahwa pada akhirnya semua manusia akan selamat. Namun berdasarkan Alkitab dikethui bahwa ada manusia yang beroleh selamat dan ada juga yang binasa atau dihukum; Paham univeraslisme juga meyakini bahwa karena kasih karunia Allah maka semua manusia akan diselamatkan. Namun berdasarkan Alkitab dapat diketahui bahwa kasih Allah akan manusia di dunia ini sehingga telah mangaruniakan Anak-Nya yang tunggal. Begitu Tuhan Yesus mati di atas kayu salib, maka ada titik peralihan - hanya orang yang percaya yang beroleh selamat, sementara yang tidak percaya Tuhan Yesus akan binasa selama-lamanya ; Selain itu, paham universlisme juga meyakini bahwa manusia dapat menyelamatkan dirinya melalui perbuatan baik. Tetapi Alkitab mengajarkan bahwa manusia diselamatkan karena kasih karunia Allah dan karena iman kepada Tuhan Yesus. Perbuatan baik manusia tidak mampu untuk menyelamatkan manusia.
\end{abstract}

Kata Kunci : universalisme ; selamat ; percaya ; alkitab.

\section{PENDAHULUAN}

Semua manusia mendambakan beroleh selamat saat Tuhan datang kelak untuk menghakimi semua umat manusia. Karena itu, berbagai pandangan tentang keselamatan telah dibahas. Di antara begitu banyak pengajaran tentang keselamatan, paham universalisme tentang keselamatan adalah hal yang sangat menarik untuk dibahas karena paham ini telah menyesatkan banyak orang. 
Soteriologi Kristen dengan jelas tertulis di dalam Alkitab, yaitu bahwa manusia diselamatkan adalah karena anugerah dari Allah. Kasih Allah yang begitu besar atas manusia sehingga Dia telah mengaruniakan Putra Tunggal-Nya, supaya setiap orang percaya kepada-Nya tidak binasa, melainkan beroleh hidup yang kekal. Keselamatan bukan karena usaha atau perbuatan manusia, melainkan karena anugerah dari Allah dan iman dari pihak manusia.

Jadi Sampurna Lima mengutip pernyataan Martin Luther sebagaimana terdapat dalam tulisan Berkhof mengatakan: Keselamatan dari murka Tuhan tidaklah bergantung kepada kesempurnaan kepatuhan manusia kepada hukum Taurat ataupun ritual-ritual buatan Gereja, melainkan hanya berdasarkan iman kepada Injil Yesus Kristus saja, telah mengubah jalannya sejarah kekristenan untuk selamanya ${ }^{1}$. Berkenaan dengan pernyataan Luther tersebut, Jadi Sampurna Lima mengatakan bahwa : Luther telah memberikan kontribusi yang sangat berharga bagi kekristenan. Luther telah melepaskan gereja dari belenggu injil palsu, yang mengatakan bahwa manusia dapat menyelamatkan diri sendiri dari murka Tuhan lewat amal, perbuatan baik, atau ritual-ritual agama ${ }^{2}$ Dengan demikian dapat diketahui bahwa manusia tidak dapat diselamatkan karena perbuatan baik atau amal . Manusia beroleh selamat hanyalah karena iman terhadap kasih karunia Allah.

Jefrie Walean mengenai pemikiran teologi tentang keselamatan menyatakan: Pemikiran teologi alkitabiah menyatakan bahwa semua orang berstatus berdosa dan hanya oleh anugerah Tuhan manusia mendapatkan keselamatan ${ }^{3}$. Semua manusia adalah orang berdosa dan hanya oleh karena anugerah dari Tuhan sehingga manusia dapat memperoleh keselamtan.

Rumusan masalah dalam penelitain ini adalah bagaimana keselamatan menurut paham universalisme bila dibandingkan dengan keselamatan sebagaimana tercantum dalam Alkitab. Tujuannya adalah supaya diperoleh pemahaman yang jelas tentang keselamatan menurut paham unversalisme, dan supaya diketahui dengan jelas keselamatan berdasarkan Alkitab. Selain itu, supaya dapat diketahui dengan jelas dimana letak kesalahan dari pemahaman keselamatan menurut universalisme. Hal itu akan membuat kaum beriman tidak mudah terombang-ambing oleh berbagaibagai rupa angin pengajaran tentang keselamatan, melainkan dengan teguh berpegang kepada kebenaran dan bertumbuh ke arah Kristus Sang Kepala. Karena itu, penulis tertarik untuk meneliti bidang soteriologi khususnya Keselamatan Universalisme Versus Soteriologi Kristen Dalam Persfektif Alkitab.

\section{PANDANGAN ALKITAB TENTANG KESELAMATAN}

Witness Lee memberikan pengertian tentang keselamatan: "Salvation refers to a person's being saved before God, which includes being forgiven of his sins, being spared from perdition, being regenerated, having the eternal life of God, and becoming a child of God". ${ }^{4}$ Beroleh selamat ditujukan kepada seseorang beroleh selamat di hadapan Allah, meliputi pengampunan atas dosa-dosanya, tidak binasa, dilahirkan kembali, memiliki hidup/hayat yang kekal Allah, dan menjadi anak Allah. Witness Lee menyatakan bahwa beroleh selamat itu meliputi beberapa hal. Karena dalam Alkitab sebutan untuk beroleh selamat itu ada beberapa istilah, yaitu pengampunan dosa, tidak binasa, dilahirkan kembali, beroleh hayat/hidup yang kekal dan menjadi anak Allah. Dapat diketahui bahwa berbicara tentang keselamatan tidak mungkin terlepas dari membahas tentang pengampunan dosa. Dosa adalah yang membuat manusia binasa. Bila seseorang telah menerima pengampunan dosa, maka dia tidak akan binasa lagi. Kaum beriman yang telah mengalami pengampunan dosa, maka orang tersebut dilahirkan

\footnotetext{
${ }^{1}$ Lima, "Injil Sebagai Kabar Tentang Kembalinya Kemuliaan Tuhan Ke Dalam Segenap Ciptaan."

${ }^{2}$ Lima.

${ }^{3}$ Walean, "Kateketika Dalam Sejarah Pemikiran Pedagosis Kristen."

${ }^{4}$ Lee, Knowing Thay You Are Saved.
} 
kembali, yaitu Allah sang hidup/hayat kekal masuk ke dalam manusia. Ketika seseorang telah memiliki hidup/hayat kekal Allah, maka orang tersebut menjadi anak Allah. Orang yang demikianlah yang beroleh selamat di hadapan Allah.

Beberapa ayat Alkitab tentang beroleh selamat dengan istilah yang berbeda-beda antara lain: Pertama tentang pengampunan dosa - 1 Yohanes 1:9 "Jika kita mengaku dosa kita, maka Ia adalah setia dan adil, sehingga Ia akan mengampuni segala dosa kita dan menyucikan kita dari segala kejahatan". Ayat lain adalah Efesus 1:7 mengatakan: "Sebab di dalam Dia dan oleh darah-Nya kita beroleh penebusan, yaitu pengampunan dosa, menurut kekayaan kasih karunia-Nya" Kedua ayat tersebut di atas membicarakan tentang pengampunan dosa. Bila dosa sudah diampuni berarti telah beroleh selamat di hadapan Allah. Hal pengampunan dosa sejalan dengan Doktrin keselamatan sebagaimana dikemukakan oleh W.A. Criswell yang mengatakan: "Ketika kita mengakui dosa kita di hadapan Tuhan, Tuhan berfirman: "Aku tidak akan mengingat lagi dosa-dosa mereka." Jadi ketika Anda sudah datang di hadapan Allah dan mengakui dosa-dosa di hadapan Tuhan dan kemudian anda kembali datang kepada Tuhan mengakui dosa-dosa Anda maka Allah akan berkata: "Dosa apa? Dosa apa? Aku tidak tahu apa

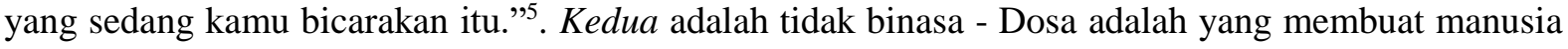
binasa. Namun bila seseorang telah mengaku dosa dan percaya kepada-Nya, maka dia mendapat pengampunan dosa dan telah beroleh selamat, sehingga tidak lagi turut dihukum. Hal inilah yang dikatakan oleh Tuhan Yesus dalam Yohanes 5:24. Melalui percaya kepada Kristus tidak hanya beroleh hayat yang kekal melainkan juga tidak lagi turut dihukum bahkan sudah berpindah dari dalam maut ke dalam hidup. Tidak ada lagi penghukuman bagi setiap orang yang ada di dalam Kristus (Roma 8:1). Demikian juga dengan Yohanes 3:16 dengan tegas mengatakan bahwa setiap orang yang percaya kepada-Nya tidak binasa melainkan beroleh hayat yang kekal. Bahkan Yohanes 10:28 lebih jelas lagi mengatakan pasti tidak akan binasa sampai selama-lamanya. Bukan mudah-mudahan, bukan pula semoga diselamatkan. Tetapi pasti tidak akan binasa sampai selama-lamanya. Hal ini sesuai sebagaimana dikemukakan oleh Utelo yang mengatakan "Yohanes 3:16 memberikan informasi hakekat keselamatan. Nats ini memperlihatkan hakekat keselamatan dalam dua aspek, yakni secara positif berarti "kehidupan kekal," dan secara negatif berarti "ketidakbinasaan." Secara sederhana, keselamatan berarti "menerima kehidupan kekal dan terhindar dari kebinasaan." Pandangan Utelo ini dengan jelas menyatakan bahwa beroleh selamat itu meliputi menerima hayat yang kekal dan tidak binasa. Ketiga Dilahirkan kembali. Tuhan Yesus dalam Yohanes 3:6 pernah berkata kepada Nikodemus bahwa dia harus dilahirkan kembali. Ayat tersebut mengatakan bahwa apa yang dilahirkan dari Roh adalah roh. Roh yang pertama mengacu kepada Roh Allah, sedangkan roh yang kedua mengacu kepada roh manusia. Hal itu berarti, Roh Allah masuk ke dalam roh manusia itulah dilahirkan kembali. Roh Allah masuk ke dalam diri manusia, menaruh hayat Allah ke dalam diri manusia. Dengan kata lain, dilahirkan kembali berarti selain hayat manusia yang diwarisi dari orang tua, ditambahkan lagi satu hayat lain yaitu hayat Allah ke dalam diri kaum beriman. 1 Petrus 1:3 mengatakan bahwa kaum beriman dilahirkan kembali melalui kebangkitan Kristus. Dilahirkan kembali membuat kaum beriman memiliki hayat kekal Allah dan dipersatukan dengan Allah. Kelahiran kembali menghidupkan kaum beriman dengan hayat Allah, membawa kaum beriman ke dalam hubungan hayat, kesatuan organik dengan Allah. Karena kelahiran kembali menghidupkan roh kaum beriman serta Allah masuk ke dalam kaum beriman, berarti sudah beroleh selamat. Keempat - Beroleh hayat/hidup yang kekal. Yohanes 3:16 dengan jelas mencatat bahwa setiap orang yang percaya kepada-Nya tidak binasa melainkan beroleh hidup yang kekal. Yohannes 5:24 juga menyatakan bahwa yang percaya Tuhan Yesus beroleh hayat yang kekal. Ayat ini dengan jelas memberi tahu bahwa bila seseorang percaya kepada Tuhan, maka dia beroleh hayat atau

\footnotetext{
${ }^{5}$ Murphy, Siniscalchi, and Patrick, "A MERICAN THEOLOGICAL INQUIRY A BIANNUAL JOURNAL OF THEOLOGY, CULTURE \& HISTORY."

${ }^{6}$ UTelo, "KONSEP SOTERIOLOGI ALKITABIAH DALAM YOHANES 3:16."
} 
hidup yang kekal. Karena memiliki Tuhan Yesus memiliki hayat yang kekal (1 Yoh. 5:12-13). Setiap orang yang telah memiliki hidup yang kekal berarti sudah beroleh selamat. Kelima-Menjadi anakanak Allah. Yohanes 1:12-13 menyatakan bahwa setiap orang yang percaya yaitu yang menerima Tuhan Yesus, maka dia menjadi anak-anak Allah. Menjadi anak-anak Allah berarti sudah beroleh selamat.

\section{Keselamatan Adalah Karena Kasih Karunia Allah}

Th.Mueller sebagaimana dikutip oleh SAM Silitonga mengatakan bahwa "Keselamatan dari Kristus itu diperoleh semua manusia melalui pekerjaan penebusan-Nya dan telah diberikan kepada orang berdosa dalam arti anugerah-anugerah". ${ }^{7}$ Mueller percaya bahwa untuk menerima keselamatan adalah karena karya penebusan Kristus. Karena semua umat manusia sudah berdosa, Tuhan Yesus datang menjadi manusia dan mati di atas kayu salib untuk mengampuni semua dosa umat manusia. Jadi, keselamatan itu bukan dari manusia, melainkan dari Allah. Tidak seorang manusia pun menyelamatkan dirinya di hadapan Allah. Namun, Allah yang penuh kasih, datang menjadi manusia untuk mengampuni segala dosa dan menyelamatkan manusia.

Pandangan yang sama tentang keselamatan dikemukakan oleh Handayani: "Keselamatan adalah anugerah Allah dan manusia hanya dapat menerima keselamatan dari Allah hanya melalui iman, bukan karena perbuatan"8. Segala hal yang berhubungan dengan syarat keselamatan telah digenapkan oleh Tuhan melalui kematian-Nya di atas salib. Iman adalah satu-satunya sarana bagi manusia untuk menerima keselamatan. Mengenai bahwa manusia diselamatkan adalah karena kasih karunia Allah dan melalui iman terhadap apa yang telah Tuhan rampungkan, lebih lanjut Handayani mengatakan 'Diselamatkan oleh anugerah adalah suatu konsep dalam teologi Kristen yang menyatakan bahwa keselamatan manusia adalah pemberian Allah semata. Dalam konsep ini, keselamatan manusia tidak ditentukan oleh perbuatan yang dilakukannya, melainkan berdasarkan anugerah dari Allah yang diterima melalui iman kepada Tuhan Yesus Kristus. Keselamatan itu bukan karena pekerjaan atau perbuatan manusia, melainkan keselamatan itu anugerah Allah '?

Pandangan Handayani ini sangat sesuai dengan yang terdapat dalam kitab Efesus 2:8 mengatakan: "Sebab karena kasih karunia kamu diselamatkan oleh iman; itu bukan hasil usahamu, tetapi pemberian Allah, 9 itu bukan hasil pekerjaanmu: jangan ada orang yang memegahkan diri”. Beroleh selamat adalah pemberian Allah. Jadi, manusia tidak dapat diselamatkan karena kebenarannya sendiri. Beroleh selamat bukan karena perbuatan manusia, tetapi karena anugerah dari Allah dan karena iman manusia.

\section{Syarat Untuk Menerima Keselamatan}

Witness Lee mengatakan bahwa beroleh selamat adalah ditujukan kepada seseorang beroleh selamat di hadapan Allah, maka Allah pasti memberi tahu bagaimana caranya seseorang itu dapat beroleh selamat, atau siapa saja yang dapat diselamatkan di hadapan Allah. Alkitab adalah satu-satunya kitab yang Allah karuniakan kepada manusia untuk dapat mengetahui maksud hati Allah. Mengenai Alkitab The eye in the Old Testament and Talmud mengatakan "Holy books are not medical manuals. They are seen by believers as completely true, although subject to interpretation and clarification, and by others as historical, spiritual, or moral guides.${ }^{10}$ Alkitab itu adalah firman Allah yang sepenuhnya

\footnotetext{
${ }^{7}$ Pdt. Sam Silitonga, "Keselamatan Yang Universal."

${ }^{8}$ Handayani, "Tinjauan Teologis Konsep Iman Dan Perbuatan Bagi Keselamatan.”

${ }^{9}$ Handayani.

${ }^{10}$ Mansour et al., "The Eye in the Old Testament and Talmud."
} 
benar dan yang mengungkapkan jalan keselamatan. Semua hal-hal yang berhubungan dengan keselamatan sudah dituangkan dalam Alkitab.

Beberapa ayat Alkitab yang menyatakan bagaimana agar seseorang dapat beroleh selamat; Markus 16:16 "Siapa yang percaya dan dibaptis akan diselamatkan, tetapi siapa yang tidak percaya akan dihukum". Ayat lain adalah sebagaimana terdapat dalam kitab Roma 10 : 13 "Sebab, barangsiapa yang berseru kepada nama Tuhan, akan diselamatkan". Kedua ayat Alkitab di atas adalah sama-sama membicarakan apa yang harus dilakukan agar seseorang itu dapat beroleh selamat di hadapan Allah. Markus 16 mencatat bahwa seseorang harus percaya dan dibaptis supaya memperoleh keselamatan. Roma 10 membicarakan harus menyeru kepada nama Tuhan baru bisa diselamatkan. Bila kedua ayat tersebut digabungkan, maka dapat diketahui ada 3 (tiga) syarat yang harus dilakukan oleh manusia agar beroleh selamat di hadapan Allah, yaitu: percaya, berseru dan dibaptis.

Mengenai Yohanes $3: 16$ Watchman Nee mengatakan : Satu fakta besar ialah, Allah mengasihi manusia di dunia ini. KasihNya begitu besar, sehingga la telah mengaruniakan Anak-Nya yang tunggal, mati di atas kayu salib bagi dosa manusia, untuk menyelamatkan orang dosa. Fakta yang alangkah besar. Di dunia ini tidak ada satu fakta lain yang lebih besar dan riil daripada ini. Menyusul itu, ada satu syarat besar yang dibentangkan di hadapan semua orang untuk dilakukan. Apakah syarat itu? Yaitu setiap orang harus percaya kepada apa yang telah Allah genapkan. Inilah satu-satunya syarat yang harus dilaksanakan oleh setiap orang. Satu fakta yang besar dikerjakan oleh Allah; satu syarat yang besar dikerjakan oleh manusia; dan apakah akibatnya? Akibatnya ialah tidak binasa, melainkan beroleh hidup yang kekal"11. Watchman Nee dengan jelas menyatakan bahwa untuk beroleh selamat harus percaya terhadap apa yang telah Tuhan Yesus rampungkan melalui kematian-Nya di atas salib. Sebagai hasil dari percaya tersebut adalah beroleh hayat/hidup yang kekal.

Beberapa ayat lain yang membicarakan tentang keselamatan adalah Yohanes 3:36 "Barangsiapa percaya kepada Anak, ia beroleh hidup yang kekal, tetapi barangsiapa tidak taat kepada Anak, ia tidak akan melihat hidup, melainkan murka Allah tetap ada di atasnya." Ayat ini membicarakan bahwa yang percaya kepada Tuhan Yesus beroleh selamat karena memiliki hidup yang kekal. Sebaliknya yang tidak taat kepada Tuhan Yesus tidak akan melihat hidup sebaliknya murka Allah tetap ada di atasnya. Selain ayat tersebut di atas, 1 Korintus 5:5 "orang itu harus kita serahkan dalam nama Tuhan Yesus kepada Iblis, sehingga binasa tubuhnya, agar rohnya diselamatkan pada hari Tuhan". Ayat ini membicarakan bahwa masih ada kebinasaan. Kedua ayat tersebut di atas sama-sama membahas bahwa kelak masih ada orang yang akan binasa.

Dengan demikian dapat diketahui bahwa Allah mengasihi semua manusia. Tuhan Yesus sudah mati di kayu salib untuk mengampuni dosa semua umat manusia. Namun, agar manusia menerima keselamatan, masih perlu peran serta manusia. Yaitu, manusia harus percaya terhadap apa yang telah Allah rampungkan melalui kematian Tuhan Yesus di atas salib. Bila manusia tidak percaya dan tidak berseru memohon keselamatan kepada Tuhan, maka manusia tersebut tetap binasa.

\section{Perbuatan Baik Tidak Dapat Menyelamatkan}

Kisah Para Rasul 4:12 mencatat "Dan keselamatan tidak ada di dalam siapa pun juga selain di dalam Dia, sebab di bawah kolong langit ini tidak ada nama lain yang diberikan kepada manusia yang olehnya kita dapat diselamatkan." Ayat ini menjelaskan bahwa keselamatan hanya ada dalam nama Tuhan Yesus. Selain Tuhan Yesus tidak ada yang bisa menyelamatkan manusia di hadapan Allah. Perbuatan baik, hukum taurat tidak ada yang bisa menyelamatkan manusia.

Paulus dengan jelas mengatakan dalam Efesus 2, bahwa keselamatan itu bukan hasil usaha, bukan perbuatan manusia, melainkan karena kasih karunia Allah. Bahkan Paulus juga mengatakan dalam Galatia 2:21 "Aku tidak menolak kasih karunia Allah. Sebab sekiranya ada kebenaran oleh hukum Taurat, maka sia-sialah kematian Kristus". Kebenaran bukan karena melakukan hukum taurat. Untuk orang berkenan di hadapan Allah bukan karena melakukan hukum taurat, melainkan karena kasih karunia Allah, karena kematian Kristus

\footnotetext{
${ }^{11}$ Nee, "Tahukah Anda Telah Beroleh Selamat."
} 
Selain itu, kitab Yesaya 64:6 mencatat: "Demikianlah kami sekalian seperti seorang najis dan segala kesalehan kami seperti kain kotor; kami sekalian menjadi layu seperti daun dan kami lenyap oleh kejahatan kami seperti daun dilenyapkan oleh angin". Kesalehan atau perbuatan baik manusia hanyalah seperti kain kotor di hadapan Allah, juga seperti daun yang bisa kering dan layu serta dilenyapkan oleh angin. Di hadapan Allah, semua perbuatan baik manusia hanyalah seperti kain kotor dan tidak bisa bertahan di hadapan Allah.

Hal ini serupa dengan yang dikemukan dalam Doktrin keselamatan : «Namun, Rasul Paulus berbicara dengan terus terang kepada mereka bahwa manusia tidak dapat diselamatkan dengan semua itu, ada cara lain agar manusia dapat diselamatkan, karena tak seorangpun dapat dibenarkan di hadapan Allah dengan kesucian dan perbuatan baiknya sendiri, karena sesunggugnya manusia tidak dapat mencapai kesucian dan kebajikan menurut standard Tuhan ${ }^{12}$. Manusia tidak dapat berbuat baik. Sekalipun dapat berbuat baik, dalam pandangan Allah hanyalah seperti kain kotor dan tidak dapat bertahan. Karena itu, manusia diselamatkan bukan karena perbuatan atau usaha manusia, tetapi karena kasih karunia Allah dan iman dari pihak manusia.

\section{PANDANGAN UNIVERSALISME TENTANG KESELAMATAN}

Mengenai universalisme N.T.Wright menyatakan: "Dalam teologi Kristen, universalisme telah digunakan dalam dua pengertian. Yang pertama secara umum diterima, dan yang kedua biasanya ditolak, kususnya oleh pemikiran ortodoks.

1. Dalam rujukan pemikiran alkitabiah, universalisme seringkali menunjukkan bahwa maksud-maksud Tuhan tidak terbatas hanya bagi bangsa atau ras tertentu, tetapi mencakup seluruh dunia. Pandangan ini biasa dalam PL dan PB. Atas dasar monotheisme, ide ini mencakup seluruh dunia sebagaimana janji Tuhan kepada Abraham (Kej. 12:3, dll), juga mencakup mereka yang non-Israel yang bergabung menjadi umat Allah (Rahab, Rut.dll).

2. Penggunaan kedua dari istilah universalisme menunjukkan bahwa semua umat manusia, tanpa terkecuali, pada akhirnya akan mendapatkan keselamatan. ${ }^{13}$

Beberapa tokoh gereja yang menganut paham universalisme antara lain: "Clement dari Alexandria (Titus Flavius Clement) yang hidup kira-kira pada tahun 150 -- 215 adalah filsuf Kristen pertama dan salah satu guru yang paling terkenal di Gereja Alexandria (Church of Alexandria). Dia terkenal karena usahanya menyatukan filosofi Yunani dengan ajaran-ajaran Kristen dan menarik sejumlah besar penyembah berhala ke gereja. Semangatnya terhadap filosofi, khususnya pada ajaranajaran Plato, berperan besar dalam penyebaran agama Kristen di Yunani. Dari dulu hingga sekarang, ia dianggap sebagai tokoh yang sangat tidak ortodoks dan kontroversial dalam sejarah gereja" ${ }^{14}$ Mengenai Clement, Donald F. John mengatakan: "Dia mengajarkan bahwa semua manusia akhirnya diselamatkan"15. Tokoh gereja berikutnya yang menganut paham universalisme adalah Origenes, dia adalah murid dari Clement. Origenes mengajarkan bahwa: "Semua umat manusia, tanpa terkecuali, pada akhirnya akan mendapatkan keselamatan. Salah satu bentuk keyakinan ini melibatkan bahwa pada masa bapa-bapa gereja ada pandangan, dalam berbagai macam tingkatan, bahwa pada akhirnya Tuhan akan memulihkan seluruh tatanan ciptaan termasuk setan kepada sebuah keadaan yang sempurna... dan sidang Kontantinopel,pada tahun 553 telah menyatakannya bersalah"16. Tokoh berikutnya adalah Schleiermacher yang menyatakan bahwa "kasih yang besar dari Allah pada akhirnya menyelamatkan

\footnotetext{
12 Purwanto, "DiSELAMATKAN OLEH ANUGERAH (SOTERIOLOGI)."

${ }^{13}$ Sinclair B. Ferguson, David F. Wright, "New Dictionary Of Theology Jilid 3."

14 "Clement Dari Alexandria | Bio-Kristi."

15 John, "Soal-Soal Kepercayaan."

${ }^{16}$ Sinclair B. Ferguson, David F. Wright, "New Dictionary Of Theology Jilid 3."
} 
semua orang semua orang dan bahwa sorga tercemar bila penghuninya dipakai menyaksikan penderitaan abadi dari para terhukum" 17

Menurut W.R.F. Browning universalisme adalah: "Kepercayaan bahwa semua manusia akhirnya akan mendapat bagian pada keselamatan, yang adalah anugerah Allah". ${ }^{18}$ Dengan demikian dapat diketahui bahwa W.R.F.Browning berpandangan bahwa pada akhirnya semua manusia akan diselamatkan

Mengenai paham universalisme David Eko Setiawan menulis: Universalisme adalah salah satu paham yang secara nyata telah mempengaruhi kekristenan. Sejarah mencatat bahwa ada beberapa tokoh gereja yang terpengaruh dan mengajarkannya sehingga menimbulkan penyesatan. Penyesatan ini berdampak pada iman sebagian orang Kristen yang kemudian menyimpang dari iman yang ortodoks. Dan fakta menunjukkan bahwa pengaruh Universalisme masih dapat dirasakan sampai sekarang ${ }^{19}$ Paham universalisme sudah menyebar dengan cukup luas. Namun ada beberapa hal penting yang menjadi inti dari paham universalisme tersebut, antara lain :

\section{Semua Manusia Pada Akhirnya Akan Diselamatkan}

Mengenai universalisme W.R.F. Browning memberikan pengertian tentang universalisme sebagai berikut : "The belief thal all human beings will ultimate share in the grace of God'salvation"20. Hal itu berarti bahwa W.R.F. Browning percaya bahwa pada akhirnya semua umat manusia akan berbagian dalam karunia keselamatan Allah. Selain itu, Browning juga mengatakan bahwa semua umat manusia, tanpa kecuali, pada akhirnya akan mendapatkan keselamatan ${ }^{21}$.

Paham keselamatan universalisme menurut Donald F. John sebagaimana dikutip oleh David Eko Setiawan, yaitu: "Universalisme adalah pandangan yang meyakini bahwa semua manusia akhirnya diselamatkan. Pandangan ini meyakini bahwa kasih Allah yang tidak terbatas akhirnya akan membebaskan manusia dan membawa semua manusia masuk sorga" 22

Pandangan serupa dikemukakan oleh Demsy Jura "Keyakinan Universalisme adalah doktrin yang percaya bahwa semua manusia; tanpa memandang agama mereka, pada akhirnya akan diselamatkan. Paham ini diyakini oleh Gereja Universalisme di Amerika Serikat. Universalisme merupakan suatu pengajaran ada di hampir dengan semua agama yang ada, yaitu: suatu ajaran yang mempercayai bahwa semua manusia yang pernah hidup di dunia ini akan diselamatkan dan masuk ke dalam kerajaan sorga, apakah ia baik atau jahat semuanya akan ada di sorga karena Allah sangat mengasihi dunia dan orang- orang berdosa. Universalisme adalah suatu doktrin yang mengajarkan bahwa pada akhirnya semua orang akan selamat, dan hal tersebut terjadi karena kasih karunia Tuhan atas seluruh umat manusia. ${ }^{23}$ Pandangan ini menyatakan bahwa karena kasih karunia Allah atas semua manusia, tanpa memandang agama maka pada akhirnya semua orang akan selamat

\section{Kasih Allah}

\footnotetext{
${ }^{17}$ Sinclair B. Ferguson, David F. Wright.

${ }^{18}$ Browning, "Kamus Alkitab a Dictionary of the Bible."

${ }^{19}$ Setiawan, "Refleksi Pastoral Terhadap Konsep Keselamatan Dalam Universalisme Ditinjau Dari Soteriologi Kristen."

${ }^{20}$ Browning, "Kamus Alkitab a Dictionary of the Bible."

${ }^{21}$ Browning.

${ }^{22}$ Setiawan, "Refleksi Pastoral Terhadap Konsep Keselamatan Dalam Universalisme Ditinjau Dari Soteriologi Kristen."

${ }^{23}$ Abstract, "MENALAR DILEMA ETIS DALAM FILM SILENCE."
} 
David Eko Setiawan mengutip bahwa kasih Allah yang tidak terbatas akhirnya akan membebaskan manusia dan membawa semua manusia masuk sorga"24. Pendapat senada juga disampaikan oleh Schleiermacher sebagaimana dikutip oleh W.R.F. Browning menyatakan: bahwa kasih yang besar dari Allah pada kahirnya menyelamatkan semua orang ${ }^{25}$ Pandangan ini meyakini bahwa karena Allah adalah kasih, maka pada akhirnya Allah akan membebaskan semua manusia dan menyelamatkan manusia. Kasih Allah menyelamatkan semua manusia di atas salib, karena itu semua manusia telah beroleh selamat.

\section{Manusia Dapat Menyelamatkan Dirinya}

Pendapat universalisme bahkan diyakini bahwa setiap manusia dapat menyelamatkan dirinya sendiri melalui perbuatan baik" ${ }^{26}$ Pandangan ini menyakini bahwa manusia dapat melakukan perbuatan baik di hadapan Allah.

\section{Perbuatan Baik Dapat Menyelamatkan Manusia}

Mengenai perbuatan dapat menyelamatkan diri sebagaimana dibahas oleh Danel F. Jhoni dibahas oleh Donald F. Johh mengenai keselamatan universalisme dikemukakan oleh Donald F. John menyatakan bahwa " Universalisme percaya bahwa manusia memperoleh keselamatannya sendiri melalui perbuatan-perbuatan baik dan bahwa setiap orang akhirnya akan diselamatkan"27. Paham ini bukan hanya menyatakan bahwa manusia dapat melakukan perbuatan baik di hadapan Allah, bahkan perbuatan baik manusia tersebut dapat membuat manusia untuk beroleh selamat di hadapan Allah.

\section{KESELAMATAN UNIVERSALISME VERSUS SOTERIOLOGI KRISTEN}

Paham universalisme yang menyatakan bahwa pada akhirnya semua manusia akan diselamatkan adalah tidak benar bahkan menyesatkan. Beberapa paham dalam universalisme yang dapat menyesatkan kaum beriman antara lain adalah: Semua manusia pada akhirnya akan diselamatkan ; Kasih Allah yang begitu dalam sehingga akan menyelamatkan semua manusia ; Manusia dapat menyelamatkan dirinya; Perbuatan baik dapat menyelamatkan manusia. Beberapa poin yang menonjol dalam paham universalisme tersebut akan dibandingkan dengan soteriologi kristen sebagaimana telah tercantum dalam Alkitab.

\section{Semua Manusia Pada Akhirnya Akan Diselamatkan}

Paham universalisme yang dianut oleh Clemen seperti dikutip oleh Donald F. John sebagaimana telah disebutkan di atas mengatakan bahwa pada akhirnya semua manusia akan diselamatkan. Hal ini bertentangan dengan firman Tuhan yang menyatakan bahwa hanya orang yang percaya yang akan diselamatkan. Yohanes 3;16 dengan jelas mengatakan supaya setiap orang yang percaya kepada-Nya tidak binasa melainkan beroleh hidup yang kekal. Ayat ini dengan jelas mengatakan bahwa hanya orang yang percaya kepada Tuhan Yesus yang tidak akan binasa, melainkan beroleh hidup yang kekal. Hal itu berarti ada yang akan selamat dan ada yang akan binasa.

Selain itu, dalam Markus 16:16 mencantumkan bahwa yang percaya dan dibaptis akan diselamatkan, tetapi yang tidak percaya akan dihukum. Ayat ini juga dengan jelas mengatakan bahwa

\footnotetext{
${ }^{24}$ Setiawan, "Refleksi Pastoral Terhadap Konsep Keselamatan Dalam Universalisme Ditinjau Dari Soteriologi Kristen."

${ }^{25}$ Browning, "Kamus Alkitab a Dictionary of the Bible."

${ }^{26}$ Setiawan, "Refleksi Pastoral Terhadap Konsep Keselamatan Dalam Universalisme Ditinjau Dari Soteriologi Kristen."

${ }^{27}$ John, "Soal-Soal Kepercayaan."
} 
ada yang beroleh selamat dan ada juga yang akan binasa. Hanya orang yang percaya Tuhan Yesus yang akan diselamatkan, sementara orang yang tidak percaya Tuhan Yesus akan dihukum. Yohanes $3: 36$ dan 1 Korintus $5: 5$ juga membahas bahwa pada akhirnya manusia masih ada yang akan binasa - orang yang tidak percaya Tuhan Yesus tidak akan melihat hidup, melainkan murka Allah tetap ada di atasnya, yaitu binasa. Berdasarkan beberapa ayat Alkitab tersebut di atas dapat diketahui bahwa ada orang yang akan beroleh selamat, namun ada juga yang akan binasa. Perbedaannya adalah masalah percaya.

Dengan demikian dapat diketahui bahwa paham universalisme yang mengatakan bahwa pada akhirnya semua manusia akan diselamatkan bertentangan dengan firman Tuhan dan sangat menyesatkan. Karena Alkitab dengan jelas menyatakan bahwa kelak ada yang beroleh selamat dan masih ada juga yang binasa. Hanya orang yang percaya terhadap karya Kristus di atas salib yang akan menerima keselamatan. Yang tidak percaya akan binasa karena dosa-dosanya

\section{KRITIK TERHADAP PANDANGAN UNIVERSALIME}

Sebagaimana telah diuraikan di atas, yaitu dari pernyataan N.T. Wright di atas bahwa ada dua pandangan tentang universalisme. Yang pertama paham universalisme yang seringkali menunjukkan bahwa maksud-maksud Tuhan tidak terbatas hanya bagi bangsa atau ras tertentu, tetapi mencakup seluruh dunia, yaitu bangsa non-Yahudi. Karena hal ini adalah sesuai dengan Perjanjian Lama dan Perjanjian Baru, maka paham yang pertama ini tidak perlu dikritik. Yang akan penulis kritik adalah paham yang kedua, yaitu menunjukkan bahwa semua umat manusia, tanpa terkecuali, pada akhirnya akan mendapatkan keselamatan. Penulis akan mengkritik paham tersebut dari tiga aspek, yaitu aspek kasih Allah, aspek manusia dapat menyelamatkan dirinya, dan dari aspek perbuatan baik dapat menyelamatkan manusia

\section{Kasih Allah}

Schleiermacher yang menyatakan bahwa kasih yang besar dari Allah pada akhirnya menyelamatkan semua orang semua orang dan bahwa sorga tercemar bila penghuninya dipakai menyaksikan penderitaan abadi dari para terhukum. Hal ini juga disampaikan oleh Damsy Jura. Paham universalisme ini menyakini bahwa karena kasih karunia Allah, maka semua manusia pada akhirnya akan diselamatkan. Semua manusia yang pernah hidup di dunia pada akhirnya akan diselamatkan walau apa pun agamnya.

Pahan ini sangat bertentangan dengan Alkitab. Karena Yohanes $3: 16$ dengan jelas memberi tahu bahwa karena begitu besar kasih Allah akan dunia ini, sehingga Dia telah mengaruniakan putraNya, yaitu Tuhan Yesus mati di atas kayu salib. Namun, ayat tersebut juga menyatakan bahwa melalui kematian Tuhan Yesus di atas salib, maka sejak saat itu ada titik peralihan (turning point), yaitu siapa yang percaya kepada-Nya beroleh hidup yang kekal dan yang tidak percaya akan binasa. Puncak kasih Allah kepada seluruh umat manusia, yaitu Dia mati untuk menyelamatkan seluruh umat manusia. Tetapi setelah melalui kematian-Nya ada suatu titik peralihan bahwa hanya yang percaya atau yang menerima Tuhan Yesus yang beroleh hidup yang kekal atau beroleh selamat, sedangkan yang tidak percaya akan tetap binasa. Secara fakta rohani, yaitu fakta objektif bahwa Tuhan Yesus sudah mati di atas salib untuk mengampuni dosa semua manusia dan untuk memperdamaikan manusia dengan Allah. Namun, fakta objektif ini perlu dipercayai oleh manusia, yaitu dengan iman percaya kepada-Nya. Dengan demikian, maka fakta objektif ini menjadi pengalaman yang subjektif bagi kaum beriman. Dengan demikian, dapat diketahui bahwa hanya orang yang percaya atau hanya orang yang menerima Tuhan Yesus yang akan beroleh selamat di hadapan Allah.

Hal itu sejalan dengan American Theological Inquiry yang mengatakan: "In essence, faith is a 
human response to divine revelation; it involves both the recognition by people that they are unable by themselves to receive the forgiveness of sins and that God has provided salvation through Jesus' death for them" 28 . Karena semua manusia sudah berdosa dan tidak ada manusia yang dapat mengampuni dosanya sendiri, namun Allah sudah menyediakan keselamatan melalui kematian Tuhan Yesus. Manusia dapat menerima keselamatan tersebut hanya melalui iman atau percaya terhadap apa yang telah Tuhan rampungkan tersebut. Dosa yang membuat manusia binasa sudah diampuni, berarti sudah diselamatkan.

Allah mengasihi semua manusia tanpa adanya perbedaan. Kasih Allah yang tidak terbatas itu dinyatakan melalui Tuhan Yesus mati di atas kayu salib untuk mengampuni semua dosa umat manusia. Hal ini terjadi adalah di pihak Allah. Namun, supaya keselamatan ini terealisir di atas manusia, maka manusia perlu percaya, yaitu beriman terhadap apa yang telah Tuhan rampungkan di atas salib. Namun, bila manusia menolak untuk percaya, atau tidak menerima Tuhan Yesus, maka orang tersebut akan binasa karena dosa-dosanya. Hal inilah yang tidak jelas dalam paham universalisme. Paham universalisme hanya melihat dari segi kasih Allah yang universal, yaitu kasih terhadap semua manusia tanpa membeda-bedakan. Paham universalisme tidak melihat bahwa kasih Allah yang luar biasa, kasih yang tidak membedakan itu telah dicurahkan kepada manusia melalui kematian Tuhan Yesus di atas salib. Tetapi setelah itu dikatakan bahwa hanya yang percaya yang beroleh hidup yang kekal dan tidak binasa (Yoh. 3:16), namun yang tidak percaya akan dihukum (Markus 16:16).

Paham universalisme ini sangat berbahaya terhadap iman orang Kristen. Karena hanya menekankan dari aspek kasih Allah terhadap semua manusia, dan manusia sudah pasti diselamatkan. Supaya seseorang memperoleh keselamatan di hadapan Allah, selain karena kasih Allah terhadap semua manusia, harus juga memperhatikan bahwa respon atau peran manusia untuk menanggapi kasih Allah tersebut. Manusia perlu percaya, barulah keselamatan itu terealisasikan atas diri manusia. Bila manusia tidak perlu percaya, maka manusia dapat bertindak seenaknya, dapat hidup dengan sembarangan, karena manusia sudah pasti akan beroleh selamat karena kasih Allah. Inilah yang membuat bahwa pahan universalisme tersebut berbahaya dan harus ditolak.

\section{Manusia Dapat Menyelamatkan Dirinya}

Paham universalisme sebagaimana di atas telah dikutip oleh David Eko Setiawan meyakini bahwa pada akhirnya manusia dapat menyelamatkan dirinya. Hal itu jelas merupakan penyesatan dan penyangkalan terhadap Alkitab. Sebab kalau manusia dapat menyelamatkan dirinya, maka sia-sialah kematian Kristus. Kisah Para Rasul 4 : 12 dengan jelas menyatakan bahwa keselamatan tidak ada di dalam siapa pun selain di dalam Dia. Keselamatan hanya ada di dalam Kristus. Manusia tidak bisa menyelamatkan dirinya. Karena manusia adalah mati karena pelanggaran dan dosa-dosa (Efesus $2: 1$ ), maka manusia tidak berdaya untuk berbuat sesuatu untuk menyenangkan Allah. Roma 3: 10 - 12 menyatakan bahwa tidak ada seorang pun yang benar, tidak ada yang berakal budi, tidak ada seorang pun yang mencari Allah. Dalam ayat itu dengan jelas Paulus menekankan bahwa manusia tidak mungkin dapat berbuat baik di hadapan Allah karena tidak ada seorang manusia pun yang benar, tidak ada yang berakal budi dan tidak seorang pun yang mencari Allah. Karena tidak ada seorang pun yang benar, maka tidak mungkin ada perbuatan yang benar. Jadi, tidak mungkin manusia dapat menyelamatkan dirinya di hadapan Allah.

\section{Perbuatan Baik Dapat Menyelamatkan Manusia}

\footnotetext{
${ }^{28}$ Murphy, Siniscalchi, and Patrick, "A MERICAN THEOLOGICAL INQUIRY A BIANNUAL JOURNAL OF THEOLOGY, CULTURE \& HISTORY."
} 
Paham universalisme juga menyakini bahwa pada akhirnya semua manusia akan diselamatkan oleh perbuatan baik. Hal ini sangat ditentang oleh Marthin Luther, karena Luther menyatakan dengan tegas bahwa keselamatan itu tidak ada hubungannya dengan perbuatan manusia ataupun usaha ritual yang dilakukan oleh manusia. Hal ini dengan jelas tercatat dalam Efesua 2 :8-9 yang menyatakan bahwa manusia diselamatkan adalah karena kasih karunia dan oleh iman. Karena tidak seorang pun yang dibenarkan di hadapan Allah karena perbuatan baik. Manusia lemah dan tak berdaya untuk berbuat sesuatu yang baik.Tapi seandainya pun manusia dapat berbuat sesuatu, tetap ditolak oleh Allah. Karena Allah hanya menerima karya penebusan yang telah dirampungkan oleh Tuhan Yesus. Paham universalisme yang meyakini bahwa setiap manusia dapat menyelamatkan dirinya sendiri melalui perbuatan baik sangat menyesatkan dan tidak sesuai dengan kebenaran Alkitab. Paulus dalam kitab Efesus dengan jelas menyatakan bahwa manusia diselamatkan adalah karena kasih karunia. Dengan jelas disebutkan bukan hasil usaha manusia juga bukan hasil pekerjaan manusia, tetapi oleh iman

Hal itu juga bertentangan dengan Yesaya $64: 6$ "Demikianlah kami sekalian seperti seorang najis dan segala kesalehan kami seperti kain kotor; kami sekalian menjadi layu seperti daun dan kami lenyap oleh kejahatan kami seperti daun dilenyapkan oleh angin". Ayat ini menjelaskan bahwa kesalehan atau perbuatan baik manusia adalah seperti kain kotor. Tidak mungkin perbuatan manusia yang seperti kain kotor itu dapat berkenan kepada Allah. Segala perbuatan baik atau kesalehan manusia hanyalah seperti kain kotor bahkan juga seperti daun yang sebentar layu dan kering serta lenyap ditiup angin. Sungguh tak dapat bertahan di hadapan Allah. Keselamatan kekal sama sekali tidak ada hubungannya dengan hasil usaha manusia, tidak ada sangkut pautnya dengan pekerjaan manusia. Keselamatan mutlak adalah karena kasih karunia Allah. Keselamatan ini adalah pemberian Allah. Peran serta manusia hanyalah iman, yaitu manusia dengan iman menerima karunia keselamatan yang telah Allah sediakan. Hanadayani mengatakan: Dengan demikian, jika seseorang ingin mengusahakan sendiri keselama tannya dengan perbuatan yang baik, baik seluruhnya ataupun sebagian saja, sesungguhnya ia menghina Allah Bapa dan Allah Anak. Mengapa? Karena hal itu menimbulkan kesan seolah-olah karya penebusan dan keselamatan yang sejak semula direncanakan oleh Anak-Nya itu belum cukup, belum selesai. Ini jelas bertentangan dengan apa yang diajarkan oleh seluruh Perjanjian Baru.

Menyatakan bahwa manusia akan diselamatkan karena perbuatan baiknya juga memberitahu bahwa paham universalisme tidak memahami apa yang menjadi persyaratan seseorang beroleh selamat di hadapan Allah. Berdasarkan injil Markus 16 dan Roma 10 menyatakan syarat yang perlu dilakukan untuk menerima keselamatan, yaitu percaya, berseru, dan dibaptis. Percaya, yaitu menerima Tuhan Yesus, mempercayai segala yang telah Tuhan rampung demi keselamatan umat manusia. Berseru adalah mengakui dengan mulut. Apa yang telah dipercayai oleh hati, lalu diakui oleh mulut. Tidak cukup hanya percaya dalam hati, harus juga berseru, yaitu mengakui dengan mulut apa yang telah dipercayai oleh hati. Kemudian dibaptis. Dibaptis adalah suatu pernyataan kepada alam semesta bahwa mulai kini kaum beriman itu bukan lagi milik Iblis, tetapi milik Tuhan Tuhan Yesus yang telah diterima dan dipercayai dalam hati, selanjutnya adalah memberi diri dibaptis. Demikianlah kaum beriman mengumumkan kepada jagat raya bahwa dia sudah menjadi milik Allah. Perbuatan manusia sama sekali tidak terhitung dan tidak ada hubungannya dengan keselamatan.

\section{KESIMPULAN}

Berdasarkan hasil penelitian dan pembahasan sebagaimana tercantum di depan, maka Paham Universalisme Versus Soteriologi Kristen Dalam Perspektif Alkitab dapat ditarik kesimpulan, yaitu bahwa keselamatan universalisme adalah paham yang menyesatkan karena tidak sesuai dengan Alkitab. Adapun paham universalisme yang bertentangan dengan Alkitab antara lain adalah: Pertama, meyakini bahwa pada akhirnya semua manusia akan selamat. Pemahaman ini menyesatkan karena Alkitab dengan jelas mengajarkan bahwa pada akhirnya ada yang akan beroleh selamat dan ada juga yang akan 
binasa, dihukum atau kena murka Allah. Istilah binasa, dihukum dan murka Allah tetap ada di atasnya adalah memiliki maksud yang sama, yaitu tidak beroleh selamat. Kedua, meyakini bahwa karena kasih karunia Allah maka pada akhirnya semua manusia akan diselamatkan. Pemahaman ini juga menyesatkan karena Allah memang mengasihi semua manusia dan Tuhan Yesus telah mati di atas kayu salib untuk mengampuni seluruh dosa umat manusia. Namun, setelah Tuhan Yesus mati di atas kayu salib untuk menggenapkan penebusan, maka ada titik peralihan bahwa barang siapa yang percaya kepada kepada Tuhan Yesus maka dia diselamatkan, tetapi yang tidak percaya akan binasa. Walaupun Kristus telah mati untuk menyelamatkan semua manusia, namun hanya yang percaya kepada Tuhan dan kepada kasih karunia keselamatan yang telah Tuhan rampungkan itu yang akan selamat. Ketiga, meyakini bahwa manusia dapat menyelamatkan dirinya. Pemahaman ini juga tidak sesuai dengan pengajaran Alkitab. Alkitab mengajarkan bahwa karena manusia adalah mati karena dosa. Hal itu berarti bahwa manusia adalah seperti orng mati, yaitu lemah dan tidak berdaya untuk berbuat apa-apa. Perbuatan manusia adalah kotor dan dosa dan tidak mungkin berkenan kepada Allah. Sekalipun manusia dapat berbuat baik, tetap ditolak oleh Allah. Karena Allah hanya berkenan kepada keselamatan di dalam Kristus bukan hasil usah manusia. Keempat, meyakini bahwa perbuatan baik dapat menyelamatkan manusia. Hal ini juga bertentangan dengan Alkitab, karena firman Tuhan mengajarkan bahwa manusia diselamatkan karena kasih karunia Allah dan karena iman kepada Tuhan Yesus. Mengandalkan perbuatan manusia untuk beroleh selamat di hadapan Allah sungguh usaha yang sia-sia. Alkitab dengan tegas memberi tahu bahwa karunia keselamatan telah dirampungkan oleh Tuhan Yesus, yang perlu manusia lakukan agar mendapatkan keselamatan dari Tuhan adalah percaya, berseru dan dibaptis. 


\section{DAFTAR PUSTAKA}

Abstract, Abel K. Aruan. "MENALAR DILEMA ETIS DALAM FILM SILENCE.” $D k$ 53, no. 9 (2015): 1689-99. https://doi.org/10.1017/CBO9781107415324.004.

Browning, W.R.F. "Kamus Alkitab a Dictionary of the Bible," 470. Jakarta: BPK Gunung Mulia, 2019.

"Clement Dari Alexandria | Bio-Kristi." Accessed July 14, 2020. https://biokristi.sabda.org/clement_dari_alexandria_filsuf_kristen_pertama.

Handayani, Dessy. "Tinjauan Teologis Konsep Iman Dan Perbuatan Bagi Keselamatan." EPIGRAPHE: Jurnal Teologi Dan Pelayanan Kristiani 1, no. 2 (2018): 91. https://doi.org/10.33991/epigraphe.v1i2.16.

John, Donald F. "Soal-Soal Kepercayaan,” 34. Gandum Mas, 1984.

Lee, W. Knowing Thay You Are Saved. Living Stream Ministry, 2005. https://books.google.co.id/books?id=Ht0wRZ\%5C_8HV0C.

Lima, Jadi Sampurna. "Injil Sebagai Kabar Tentang Kembalinya Kemuliaan Tuhan Ke Dalam Segenap Ciptaan.” Evangelikal: Jurnal Teologi Injili Dan Pembinaan Warga Jemaat 4, no. 1 (2020): 1. https://doi.org/10.46445/ejti.v4i1.169.

Mansour, Ahmad M., Daniel Gold, Haytham I. Salti, and Zaher M. Sbeity. "The Eye in the Old Testament and Talmud." Survey of Ophthalmology 49, no. 4 (2004): 446-53. https://doi.org/10.1016/j.survophthal.2004.04.012.

Murphy, Gannon, Glenn Siniscalchi, and Stephen Patrick. "A MERICAN THEOLOGICAL INQUIRY A BIANNUAL JOURNAL OF THEOLOGY, CULTURE \& HISTORY” 5, no. 1 (2012). http://www.atijournal.org.

Nee, Watchman. "Tahukah Anda Telah Beroleh Selamat." Surabaya: Yayasan Perpustakaan Injil, 2005.

Pdt. Sam Silitonga, M.Th. "Keselamatan Yang Universal," 5. Penerbit Mitra (IKAPI), 2012.

Purwanto, Dr. W.A. Criswell Dr. Eddy Peter. "DISELAMATKAN OLEH ANUGERAH (SOTERIOLOGI)," 1st ed., 1-94. SEKOLAH TINGGI TEOLOGI INJILI PHILADELPHIA, 2006.

Setiawan, David Eko. "Refleksi Pastoral Terhadap Konsep Keselamatan Dalam Universalisme Ditinjau Dari Soteriologi Kristen.” FIDEI: Jurnal Teologi Sistematika Dan Praktika 1, no. 2 (2018): 250-69. https://doi.org/10.34081/fidei.v1i2.8.

Sinclair B. Ferguson, David F. Wright, J.I. Packer. "New Dictionary Of Theology Jilid 3," Jilid 3. Malang: Literatur SAAT, 2015.

UTelo, Ari. "KONSEP SOTERIOLOGI ALKITABIAH DALAM YOHANES 3:16," n.d.

Walean, Jefrie. "Kateketika Dalam Sejarah Pemikiran Pedagosis Kristen." Evangelikal: Jurnal Teologi Injili Dan Pembinaan Warga Jemaat 2, no. 2 (2018): 105. https://doi.org/10.46445/ejti.v2i2.108. 